\title{
Serum gonadotrophin levels in prepubertally castrated male sheep treated for long periods with propionated testosterone, dihydrotestosterone, 19-hydroxytestosterone or oestradiol
}

\author{
R. F. Parrott* and R. V. Davies \\ A.R.C. Institute of Animal Physiology, Babraham, Cambridge CB2 4AT, U.K.
}

\begin{abstract}
Summary. At different times of the year, groups of wethers were treated with $20 \mathrm{mg}$ testosterone, dihydrotestosterone or 19-hydroxytestosterone propionates/day or 2 $\mathrm{mg}$ oestradiol dipropionate/day, or the oil vehicle, for 6 weeks after a 2-week control period. LH and FSH values were determined by radioimmunoassay of serum samples collected at regular intervals. Oestradiol and dihydrotestosterone reduced LH and FSH concentrations whereas 19-hydroxytestosterone and testosterone had no effect.
\end{abstract}

\section{Introduction}

Steroidal modulation of gonadotrophin levels in the male sheep has been investigated mainly by means of single or a short-term series of injections followed by intensive sampling and subsequent radioimmunoassay. Usually, such experiments have been carried out in domesticated breeds of sheep maintained under natural daylight conditions. These studies have indicated that testosterone, or its propionate, reduces the elevated levels of luteinizing hormone (LH) and follicle-stimulating hormone (FSH) that are characteristic of the castrated ram (Pelletier, 1970; Crim \& Geschwind, 1972; Schanbacher \& Ford, 1977). Similarly, it has been shown that oestradiol reduces gonadotrophin concentrations in wethers (Riggs \& Malvern, 1974; Karsch \& Foster, 1975) and is more effective in this respect than testosterone (Schanbacher \& Ford, 1977). In contrast, dihydrotestosterone, the $5 \alpha$-reduced metabolite of testosterone, was reported to have no negative feedback effect in castrated male sheep (Schanbacher \& Ford, 1977).

The primary aim of the present experiment was to investigate the effects on serum FSH and LH levels of long-term steroid treatment in prepubertally castrated male sheep (wethers). In addition to comparing the actions of testosterone, oestradiol and dihydrotestosterone propionates, the activity of 19-hydroxytestosterone was studied. This steroid is an androgen/ oestrogen intermediate which produces modest reductions in $\mathrm{LH}$ release in castrated rhesus monkeys (Phoenix, 1976) but is unable to prevent compensatory ovarian hypertrophy in the unilaterally ovariectomized female rat (Parrott \& Booth, 1976).

The secondary aim of this study was concerned with the interaction between daylength and gonadotrophin levels in wethers. Decreasing daylength results in increased gonadotrophin concentrations in rams of domesticated breeds housed under natural or semi-natural lighting regimens (Schanbacher \& Ford, 1977; Davies, Main \& Setchell, 1977) and in Soay rams exposed to artificial photoperiods (Lincoln, Peet \& Cunningham, 1977; Lincoln \& Peet, 1977). Similarly, LH levels are higher in wethers kept under 8-h daylengths than in those maintained in 16-h photoperiods (Pelletier \& Ortavant, 1975). However, the effects of seasonal variations in daylength on $\mathrm{LH}$ and FSH levels in wethers have not been investigated. 


\section{Materials and Methods}

The animals, aged between 15 and 30 months at the start of the sampling period, were 20 Clun Forest wethers castrated on the day after birth with a rubber ring emasculator. During the experiment the animals were housed in a large shed illuminated by natural daylight.

The wethers were allocated to 4 replicate groups $(N=5 /$ group) which were studied at different times of the year. The 5 sheep in each group received no treatment for the first 2 weeks of the experiment, then throughout the following 6 weeks individual animals were given daily 1 $\mathrm{ml}$ subcutaneous injections, 5 days per week. Treatments were as follows: testosterone (4androsten-17 $\beta$-ol-3-one) propionate, dihydrotestosterone ( $5 \alpha$-androstan-17 $\beta$-ol-3-one) propionate, 19-hydroxytestosterone (17 $\beta$-hydroxy-4-androsten-19-ol-3-one) dipropionate, all of which were given at a dose of $20 \mathrm{mg} / \mathrm{day}$, and oestradiol $(1,3,5,(10)$-oestratrien-3,17 $\beta$-diol) dipropionate, $2 \mathrm{mg} / \mathrm{day}$. 19-Hydroxytestosterone dipropionate was generously donated by Merrell-National Laboratories, Cincinnati, Ohio, U.S.A.; the other hormones were obtained from Steraloids Ltd, Croydon, U.K. The vehicle for all the hormones was arachis oil.

The starting dates for the 8-week periods for the 4 replicate groups were as follows: Group 1, 4/4/77; Group 2, 13/6/77; Group 3, 22/8/77; and Group 4, 24/10/77. Each week, 3 jugular vein blood samples of $10 \mathrm{ml}$ were collected at hourly intervals from all the animals every Tuesday afternoon. Blood was withdrawn into tubes containing a separation aid (Serum Monovette: Sarstedt Ltd, Leicester, U.K.), allowed to stand for $20 \mathrm{~min}$ and then centrifuged. All serum samples were stored at $-20^{\circ} \mathrm{C}$ until assayed.

Ovine LH and FSH were measured in sera by a double-antibody radioimmunoassay. LH was measured using an antiserum to $\mathrm{NIH}$-ovine-LH-S18, raised in a rabbit at this Institute. The highly purified ovine LH used for iodination was supplied by Dr L. E. Reichert (LER 1056 C-2). The results are expressed as ng equivalents of $\mathrm{NIH}-\mathrm{LH}-\mathrm{S} 18 / \mathrm{ml}$. FSH was measured using an antiserum to NIH-ovine-FSH-S9, raised in a rabbit by Dr J. Th. J. Uilenbroek. The highly purified FSH used for iodination was NIAMDD-rat-FSH-13. The results are expressed as ng NIH-FSH-S $10 / \mathrm{ml}$.

The extent of the cross-reactions for the antisera are shown in Table 1 . The only significant cross-reaction was that of ovine TSH in the ovine LH assay (14\%). For the measurement of ovine LH it was found necessary to equalize serum concentrations in standard and sample tubes by using hypophysectomized ewe serum. Serial dilutions of castrated ram serum gave doseresponse curves which were parallel to the standard curves in the FSH and LH assays. Recoveries of gonadotrophins added to serum from a hypophysectomized ewe were complete. The detection limits of the assays were $0.4 \mathrm{ng} \mathrm{LH} / \mathrm{ml}$ and $35 \mathrm{ng} \mathrm{FSH} / \mathrm{ml}$ and the intra-assay coefficients of variation for FSH and $\mathrm{LH}$ were 12 and $10.5 \%$ respectively; all samples were processed in one assay.

Table 1. Cross-reactions among sheep gonadotrophins and TSH in the ovine FSH and $\mathrm{LH}$ radioimmunoassays

\begin{tabular}{lcc}
\hline & \multicolumn{2}{c}{ Immunochemical potency* } \\
\cline { 2 - 3 } & FSH assay & LH assay \\
\hline NIH-ovine-FSH-S10 & 1.0 & 0.003 \\
NIH-ovine-LH-S18 & $<0.01$ & 1.0 \\
NIH-ovine-TSH-S6 & $<0.05$ & 0.14 \\
Ovine LH (LER 1056 C-2) & $<0.01$ & 3.7 \\
\hline
\end{tabular}

* Determined from the weights of hormones required to displace $50 \%$ of the labelled antigens bound to the antisera. 
Mean levels of LH and FSH were calculated from the results obtained from the 3-h samples taken from a particular animal on a given day. These means were then used in a computerized analysis of variance (ANOVA) which examined the effects of treatment and time on gonadotrophin levels.

\section{Results}

The effects of the various steroid treatments on serum LH and FSH levels are shown in Text-figs 1 (a) and 1(b) respectively. Analysis of variance revealed that there were no differences between the groups, for either gonadotrophin, during the control period (Weeks 1 and 2), or in Week 3, but thereafter the intergroup differences were highly significant $(P<0.01)$.
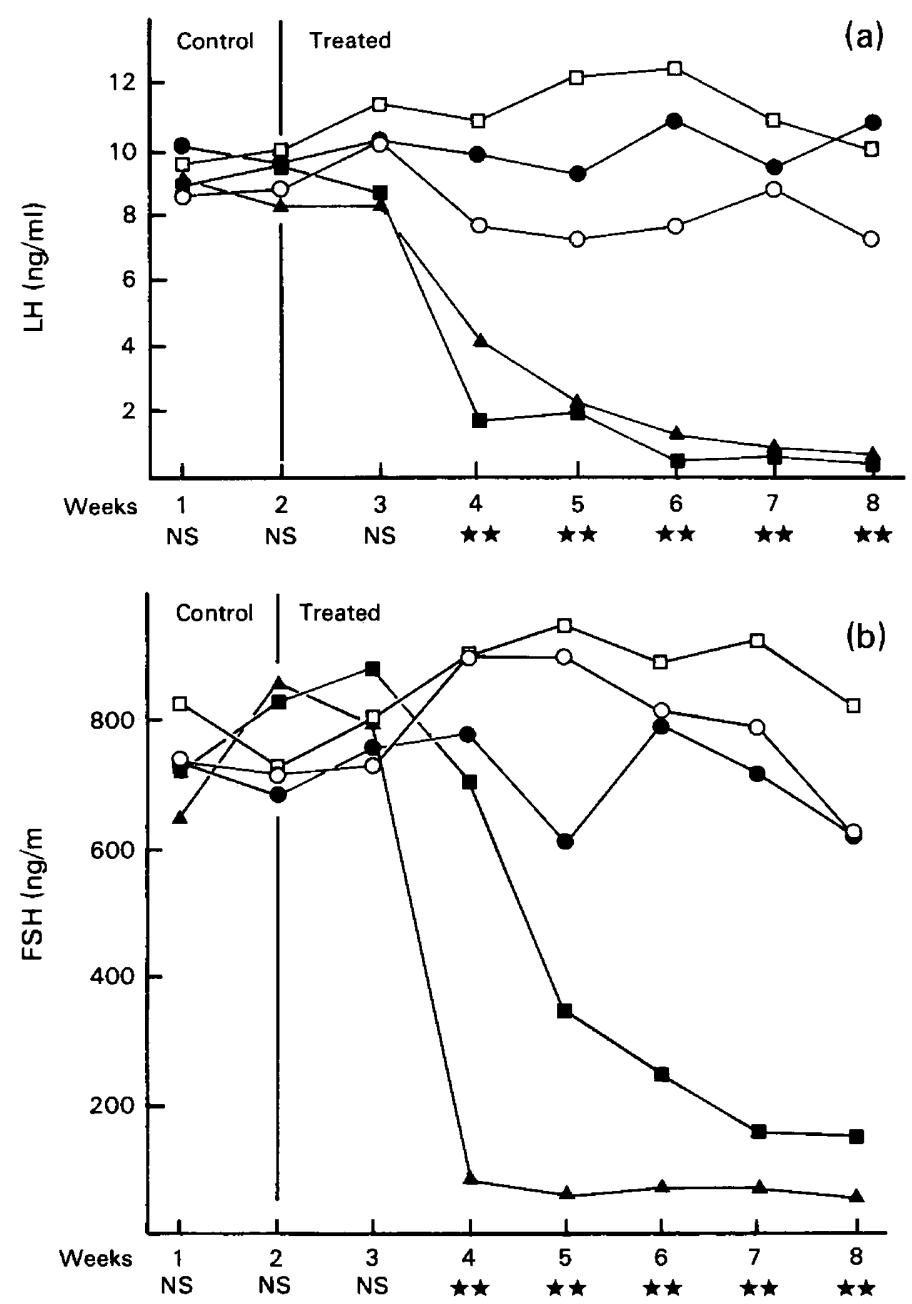

Text-fig. 1. Mean serum concentrations of (a) LH and (b) FSH in groups of wethers (4 animals per treatment) before and after administration of arachis oil $(\boldsymbol{\bullet})$; testosterone propionate $(O)$; dihydrotestosterone propionate $(\square)$; 19-hydroxytestosterone dipropionate ( $\square$ ); oestradiol dipropionate $(\boldsymbol{A})$. Differences between the treatment effects were examined each week by analysis of variance (ANOVA), ${ }^{* *} P<0.01$. 
Highly significant reductions in the serum concentrations of both gonadotrophins were produced by treatment with dihydrotestosterone and oestradiol propionates. These results are shown in Table 2 in which the levels attained in Weeks 6-8 are compared with those found during the control period.

Table 2. Change in gonadotrophin concentrations of wethers (4/group) after treatment with steroids

\begin{tabular}{|c|c|c|c|c|c|c|}
\hline \multirow[b]{2}{*}{ Treatment } & \multicolumn{3}{|c|}{ LH } & \multicolumn{3}{|c|}{ FSH } \\
\hline & $\begin{array}{r}\text { Mea } \\
(r\end{array}$ & $\begin{array}{l}n \text { change } \\
\mathrm{g} / \mathrm{ml} \text { ) }\end{array}$ & $\begin{array}{l}\text { Comparison } \\
\text { with oil } \\
(t \text { test })\end{array}$ & $\begin{array}{r}\text { Mea } \\
\text { (r }\end{array}$ & $\begin{array}{l}\text { a change } \\
\mathrm{g} / \mathrm{ml} \text { ) }\end{array}$ & $\begin{array}{c}\text { Comparison } \\
\text { with oil } \\
(t \text { test })\end{array}$ \\
\hline $\begin{array}{l}\text { Oil vehicle } \\
\text { Testosterone propionate } \\
\text { Dihydrotestosterone propionate } \\
\text { 19-Hydroxytestosterone dipropionate } \\
\text { Oestradiol dipropionate }\end{array}$ & $\begin{array}{l}+0.5 \\
-0.7 \\
-8.7 \\
+1.3 \\
-8.6\end{array}$ & $\pm 1 \cdot 0$ & $\begin{array}{c}\overline{\mathrm{NS}} \\
P<0.001 \\
\mathrm{NS} \\
P<0.001\end{array}$ & $\begin{array}{l}+3 \cdot 8 \\
+14 \cdot 7 \\
-588 \cdot 6 \\
+116 \cdot 9 \\
-717 \cdot 4\end{array}$ & $\pm 123 \cdot 6$ & $\begin{array}{c}\overline{\mathrm{NS}} \\
P<0.01 \\
\mathrm{NS} \\
P<0.001\end{array}$ \\
\hline
\end{tabular}

Values given are the mean \pm s.e.m. of the difference between control levels (Weeks 1 and 2 ) and those obtained in Weeks 6,7 and 8. Standard errors were derived from pooled estimates in the analysis of variance (ANOVA).

An unexpected feature of the results is the relative lack of depression of gonadotrophin levels by testosterone propionate treatment (Text-figs 1(a) and 1(b); Table 2). Inspection of the data revealed that testosterone propionate reduced LH and FSH levels only in the animal in the second replicate group (Table 3 ). This wether was in the group exposed to the longest natural photoperiod (Text-fig. 2).

Table 3. Mean \pm s.e.m. serum LH and FSH levels in 4 wethers before and after treatment with the same dose of testosterone propionate at different times of the year

\begin{tabular}{|c|c|c|c|c|c|}
\hline \multirow[b]{2}{*}{ Animal } & \multirow[b]{2}{*}{$\begin{array}{c}\text { Time of } \\
\text { year }\end{array}$} & \multicolumn{2}{|c|}{$\mathbf{L H}(\mathrm{ng} / \mathrm{ml})$} & \multicolumn{2}{|c|}{ FSH (ng/ml) } \\
\hline & & $\begin{array}{c}\text { Control } \\
\text { (Weeks } 1 \text { and 2) }\end{array}$ & $\begin{array}{c}\text { Treated } \\
\text { (Weeks 6-8) }\end{array}$ & $\begin{array}{c}\text { Control } \\
\text { (Weeks } 1 \text { and 2) }\end{array}$ & $\begin{array}{c}\text { Treated } \\
\text { (Weeks 6-8) }\end{array}$ \\
\hline 1 & April-May & $10 \cdot 0 \pm 0.9$ & $11.8 \pm 0.9$ & $659.5 \pm 52.6$ & $1098.4 \pm 80.0$ \\
\hline 2 & June-Aug. & $6.9 \pm 0.5$ & $0.6 \pm 0.2$ & $441.7 \pm 23.9$ & $135.4 \pm 20.1$ \\
\hline 3 & Aug.-Oct. & $7.6 \pm 0.6$ & $8.5 \pm 0.7$ & $717 \cdot 3 \pm 79 \cdot 1$ & $668.1 \pm 25.8$ \\
\hline 4 & Oct.-Dec. & $10.2 \pm 0.5$ & $10 \cdot 8 \pm 0.8$ & $1085 \cdot 8 \pm 82.0$ & $1061.4 \pm 67 \cdot 1$ \\
\hline
\end{tabular}

Control values were obtained from 6 serum samples and treated values from 9 serum samples for each animal.

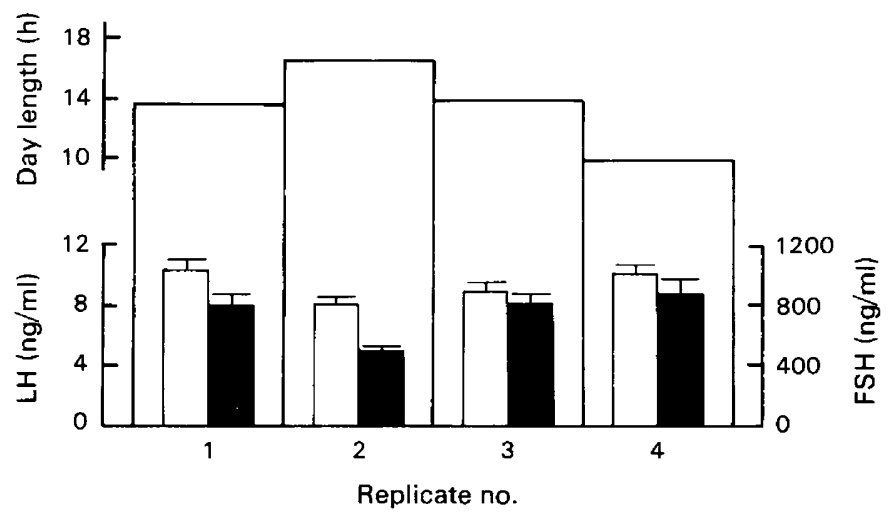

Text-fig. 2. Mean \pm s.e.m. serum levels of LH (open columns) and FSH (closed columns) in 4 groups of wethers (5/group) sampled for 2 -week periods under different conditions of natural daylight (see text for details). Differences between groups were significant $(P<0.05$, ANOVA). 
The effect of daylength on LH and FSH in wethers was examined using all the control data from the 4 replicate groups. This was obtained from the samples collected in the period before treatment began (Weeks 1 and 2). The results (Text-fig. 2) indicate that mean levels at $\mathrm{LH}$ and FSH were lowest in the group exposed to the longest natural photoperiod. Analysis of variance indicated that the differences in both gonadotrophin levels between the various daylength groups were significant $(P<0.05)$. These findings support those obtained in previous studies using wethers exposed to artificial photoperiods (Pelletier \& Ortavant, 1975).

\section{Discussion}

The results of this study show that long-term treatment of wethers with dihydrotestosterone propionate or oestradiol dipropionate produces a marked reduction in gonadotrophin levels. The negative feedback action of oestradiol dipropionate is not surprising since similar results have been obtained in wethers following administration of the free steroid, either as a single injection (Schanbacher \& Ford, 1977), or as subcutaneous implants (Riggs \& Malvern, 1974; Karsch \& Foster, 1975). However, in the present study, continuous treatment produced a $90 \%$ reduction in the levels of both gonadotrophins whereas Schanbacher \& Ford (1977) found that a single injection reduced LH by a similar amount but caused only a $30 \%$ depression in FSH levels.

The results obtained for dihydrotestosterone propionate in our experiment are also at variance with those of Schanbacher \& Ford (1977) who failed to detect any negative feedback effect following a single injection of $25 \mathrm{mg}$ free steroid. The use of the long-acting ester and the continuous injection protocol we employed are probably responsible for the different findings. Presumably, following a single administered dose, insufficient hormone reaches the hypothalamo-pituitary axis to exert an effect. Our findings concerning the effects of dihydrotestosterone propionate in wethers are similar to those previously described for the castrated male rat (Verjans, Eik-Nes, Aafjes, Vels \& van der Molen, 1974).

Treatment with 19-hydroxytestosterone dipropionate failed to reduce gonadotrophin levels; this result is similar to that obtained for the femále rat (Parrott \& Booth, 1976). This steroid undergoes aromatization within the brain and in this way induces limited sexual activity in wethers (Parrott, 1979). However, it is clear from the present experiment that insufficient oestrogen was formed in the hypothalamic regions controlling releasing-hormone production or secretion to exert any negative feedback effect. In fact, the results suggest the opposite (Table 2; Text-fig. 1b). This tendency towards positive feedback could be due to low levels of oestrogen formed by incomplete aromatization. Low doses of oestrogen elevate gonadotrophin levels in castrated male rats whereas higher doses are inhibitory (Swerdloff \& Walsh, 1973; Labrie et al., 1978); similar results have been obtained in rhesus monkeys (Karsch, Dierschke \& Knobil, 1973). However, oestradiol does not appear to have any positive feedback effect on LH in rams castrated as adults (Karsch \& Foster, 1975) although some fully androgenized ewes retain this response (Clarke, Scaramuzzi \& Short, 1976). Rams castrated on the day after birth may exhibit an intermediate condition.

The results from our wethers treated with testosterone propionate indicate that there may be a seasonally induced change in negative feedback sensitivity, although the number of animals involved was small. However, this suggestion is supported by those of a previous study (Pelletier \& Ortavant, 1975) in which the same dose of testosterone propionate was twice as effective in reducing $\mathrm{LH}$ concentrations in wethers exposed to 16 -h photoperiods than in those receiving illumination for $8 \mathrm{~h}$.

In the intact ram it is unlikely that endogenous oestrogen plays a major role in the control of gonadotrophin secretion or release since the levels encounted are low and do not vary with the season (Schanbacher \& Ford, 1976). The action of oestradiol dipropionate at the dose used in the present experiment, therefore, must be regarded as being pharmacological rather than 
physiological. Similarly, the lack of seasonal variation in the response to dihydrotestosterone propionate treatment suggests that the dose may have been supra-physiological. In males of many species circulating concentrations of dihydrotestosterone are low and since this also appears to be true of the sheep (S. J. Main \& R. V. Davies, unpublished results), dihydrotestosterone may not influence gonadotrophin release directly in the intact ram. A more likely course of events is that endogenous testosterone acts as a pro-hormone which is converted to dihydrotestosterone in the hypothalamus by $5 \alpha$-reductase enzyme systems. This centrally formed dihydrotestosterone may then influence the releasing-hormone system directly.

Oestradiol and dihydrotestosterone propionates reduced LH levels by the same amount but dihydrotestosterone propionate was not as effective as oestradiol dipropionate in suppressing FSH. If dihydrotestosterone is the active feedback hormone, then some other factor such as 'inhibin' (Setchell, Davies \& Main, 1977) may supplement its suppressive action on FSH release.

We are grateful for financial support from the Animal Health Trust and the World Health Organization. We also thank Mr D. E. Walters of the A.R.C. Statistics Group, University of Cambridge, for analysing the results and Dr B. P. Setchell, A.R.C., Babraham, for discussing the manuscript.

\section{References}

Clarke, I.J., Scaramuzzi, R.J. \& Short, R.V. (1976) Sexual differentiation of the brain: endocrine and behavioural responses of androgenized ewes to oestrogen. J. Endocr. 71, 175-176.

Crim, L.W. \& Geschwind, I.I. (1972) Patterns of FSH and $\mathrm{LH}$ secretion in the developing ram: the influence of castration and replacement therapy with testosterone propionate. Biol. Reprod. 7, 47-54.

Davies, R.V., Main, S.J. \& Setchell, B.P. (1977) Seasonal changes in plasma follicle-stimulating hormone, luteinizing hormone and testosterone in rams. $J$. Endocr. 72, 12P.

Karsch, F.J. \& Foster, D.L. (1975) Sexual differentiation of the mechanism controlling the preovulatory discharge of luteinizing hormone in sheep. Endocrinology 97, 373-379.

Karsch, F.J., Dierschke, D.J. \& Knobil, E. (1973) Sexual differentiation of pituitary function: apparent differences between primates and rodents. Science, N.Y. 179, 484-486.

Labrie, F., Lagacé, L. Feland, L., Kelly, P.A., Drouin, J., Massicotte, J., Bonne, C., Raynaud, J.-P. \& Dorrington, J.H. (1978) Interactions between LHRH, sex steroids and 'inhibin' in the control of $\mathbf{L H}$ and FSH secretion. Int. J. Androl., Suppl. 2, 81-101.

Lincoln, G.A. \& Peet, M.J. (1977) Photoperiodic control of gonadotrophin secretion in the ram: a detailed study of the temporal changes in plasma levels of follicle-stimulating hormone, luteinizing hormone and testosterone following an abrupt switch from long to short days. J. Endocr. 74, 355-367.

Lincoln, G.A., Peet, M.J. \& Cunningham, R.A. (1977) Seasonal and circadian changes in the episodic release of follicle-stimulating hormone, luteinizing hormone and testosterone in rams exposed to artificial photoperiods. J. Endocr. 72, 337-349.

Parrott, R.F. (1979) Courtship and copulation in prepubertally castrated male sheep (wethers) treated with $17 \beta$-oestradiol, aromatizable androgens or dihydrotestosterone. Horm. Behav. (in press).
Parrott, R.F. \& Booth, J.E. (1976) Failure of 19 hydroxylated androgens to inhibit compensatory ovarian hypertrophy in the rat. $J$. Endocr. 68, 173.

Pelletier, J. (1970) Mode of action of testosterone propionate on the secretion and release of luteinizing hormone $(\mathrm{LH})$ in the castrated ram. Acta endocr. Copenh. 63, 290-298.

Pelletier, J. \& Ortavant, R. (1975) Photoperiodic control of $\mathrm{LH}$ release in the ram. II. Light-androgens interaction. Acta endocr., Copenh. 78, 442-450.

Phoenix, C.H. (1976) Sexual behaviour of castrated male rhesus monkeys treated with 19-hydroxytestosterone. Physiol. Behav. 16, 305-310.

Riggs, B.L. \& Malvern, P.V. (1974) Spontaneous patterns of $\mathrm{LH}$ release in castrate male sheep and the effects of exogenous estradiol. J. Anim. Sci. 38, 1239-1244.

Schanbacher, B.D. \& Ford, J.J. (1976) Seasonal profiles of plasma luteinizing hormone, testosterone and estradiol in the ram. Endocrinology 99, 752-757.

Schanbacher, B.D. \& Ford, J.J. (1977) Gonadotrophin secretion in cryptorchid and castrate rams and the acute effects of exogenous steroid treatment. Endocrinology 100, 387-393.

Setchell, B.P., Davies, R.V. \& Main, S.J. (1977) Inhibin. In The Testis, Vol. IV, pp. 189-238. Eds A. D. Johnson \& W. R. Gomes. Academic Press, New York.

Swerdloff, R.S. \& Walsh, P.C. (1973) Testosterone and oestradiol suppression of LH and FSH in adult male rats: duration of castration, duration of treatment and combined treatment. Acta endocr., Copenh. 73, 11-21.

Verjans, H.L., Eik-Nes, K.B., Aafjes, J.H., Vels, F.J.M. \& van der Molen, H.J. (1974) Effects of testosterone propionate, $5 \alpha$-dihydrotestosterone propionate and oestradiol benzoate on serum levels of LH and FSH in the castrated adult male rat. Acta endocr., Copenh. 77, 643-654.

Received 16 October 1978 